
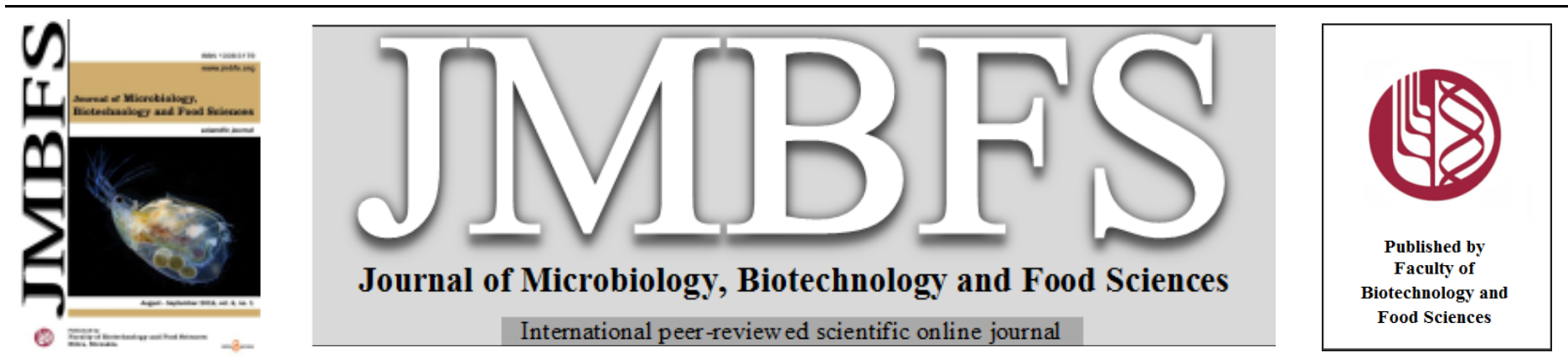

\title{
SPECIFICITY OF ADHESION OF BACILLUS SUBTILIS IMV B-7023 TO ABIOTIC AND BIOTIC SURFACES
}

\author{
Ivan Kurdish ${ }^{a}$, Alla Roy, Dmytro Dyrenko, Kateryna Hetman, Emma Kovalenko
}

Address(es):
${ }^{a}$ Zabolotny Institute of Microbiology and Virology, NAS of Ukraine, 154, Acad. Zabolotny Str., 03143, Kyiv, Ukraine tel: +38 (044) 5261190.

*Corresponding author: Kurdish@serv.imv.kiev.ua

doi: 10.15414/jmbfs.2016.6.1.652-654

ARTICLE INFO

Received 11. 11. 2015

Revised 4. 3. 2016

Accepted 6. 3. 2016

Published 1. 8. 2016

Regular article

open $\mathcal{O}$ access

\begin{abstract}
The adhesion of Bacillus subtilis strain IMV B-7023 cells to surfaces of different nature was studied. It was demonstrated that the sorption of cells to abiotic solid materials was considerably governed by the bacterial motility which depended on the growth phase. An important role in the interaction process involving cells and biotic surfaces was attributed to bacterial lectins. It was determined that surface lectins of $B$. subtilis specific for D-glucosamine chloride and, in a lesser degree, to D-glucuronic and D-galacturonic acids were also active participants of specific adhesion of bacteria to plant roots. The blockage of these lectins with D-glucosamine chloride caused bacterial adhesion to the plant roots by $26 \%$. Thus different mechanisms may be involved into the adhesion process of bacterial cells to abiotic and biotic surfaces.
\end{abstract}

Keywords: Bacillus subtilis, adhesion, surface lectins, solid materials, biotic surface

\section{INTRODUCTION}

The main part of microbiota in soil is known to function due to its contact with soil particles, vegetable debris and their roots (Costerton et al. 1985). The process of bacteria adhesion is one of the primary stages of their contact interaction with solid surfaces which then results in the multiplication of cells on surfaces and their colonization (Zviagintsev et al. 1977). According to the literature data, the main factors, determining the adhesion of microorganisms to abiotic surfaces, are physical and chemical properties of contact surfaces, namely, their charge and hydrophobicity (Kurdish 2010).

During the adhesion of bacteria to biotic surfaces, plant roots in particular, an important role is played by specific interaction between certain sites of plant root cells and microorganisms. This process is grounded on the principle of complementarity of interacting structures where the leading role is attributed to the lectin-carbohydrate interaction (Nikitina 2001; Karpunina 2005). The literature data testify to the presence of lectins on the surface of cells of sporeforming microorganisms (Karpunina 2005; Podgorsky et al. 1992; Sharon and Lis 2007). The specificity of the lectins of Bacillus subtilis IMV B-7023 which is a component of a highly efficient complex bacterial preparation used in agriculture and the lectins impact on the adhesion of cells to plant roots has not been studied yet. Our work was aimed at the comparative study of the specificities of B. subtilis IMV B-7023 adhesion to abiotic and biotic surfaces, the determination of the presence and specificity of lectins of these bacteria and their impact on the adhesion process to the surface of plant roots. The determination of the regularities of this process will help to understand the specificities of bacteria-plants interactions when the microorganisms are introduced into agroecosystems.

\section{MATERIALS AND METHODS}

\section{Microorganisms, nutrient media and culture conditions}

The object of the research was a highly efficient strain of phosphate-mobilizing bacteria Bacillus subtilis IMV B-7023 selected at the Department of Microbiological Processes on Solid Surfaces, Zabolotny Institute of Microbiology and Virology, National Academy of Science of Ukraine (Patent No. 54923A)

The hydrophilic particles of glass, representing the wide-spread in different types of soils silicates, were used as the abiotic surfaces. The roots of cucumber plants of Konkurent cultivar were used as a model of biotic surface, as the seeds of this cultivar are easy to sterilize and germinate.

The cultivation of bacteria was performed for $18-72 \mathrm{~h}$ at $28^{\circ} \mathrm{C}$ under periodic conditions in the shaker (240 rpm) using $750 \mathrm{~mL}$ Erlenmeyer flasks with $100 \mathrm{ml}$ of the medium as follows $(\mathrm{g} / \mathrm{L})$ : $\left(\mathrm{NH}_{4}\right)_{2} \mathrm{SO}_{4}-0.5 ; \mathrm{MgSO}_{4} \cdot 7 \mathrm{H}_{2} \mathrm{O}-0.3 ; \mathrm{NaCl}-$ $0.3 ; \mathrm{KCl}-0.3 ; \mathrm{MnSO}_{4} \cdot 5 \mathrm{H}_{2} \mathrm{O}-0.001 ; \mathrm{FeSO}_{4}-0.001 ; \mathrm{CaCO}_{3}-0.5$; calcium glycerophosphate -2.0 ; glucose -10.0 ; $\mathrm{pH}$ of the medium 6.8-7.0. The medium was inoculated with $1 \mathrm{~mL}$ of bacterial suspension containing $10^{9}$ cells $/ \mathrm{mL}$.

\section{Determination of adhesion of bacteria}

The study of bacterial adhesion to the abiotic surface involved the use of chemically pure glass flasks with the inside diameter of $16 \mathrm{~mm}$ and the height of $180 \mathrm{~mm}$, which were introduced with $15 \mathrm{~g}$ of chemically pure $1-2 \mathrm{~mm}$ glass particles each. Each tube was added with $6 \mathrm{ml}$ bacterial suspension to ensure complete covering of the carrier layer. After the contact with the adsorbent for 2 $\mathrm{h}$ the suspension was poured off with subsequent determination of the difference in its optic density prior to the interaction with the carrier and after it. After making obtained suspension up to the initial volume itse optic density was determined using the photocolorimeter KFK-2 MP (Zagorsk,Russia), (wavelength $540 \mathrm{~nm}$, cuvette $5 \mathrm{~mm}$ ). The number of bacteria in suspensions prior and after their interaction with the carrier was defined by the curve of optical density versus the number of cells (Gordienko et al. 2009) and the number of cells, sorbed per $1 \mathrm{~g}$ of glass granules, was estimated.

The bacteria adhesion to cucumber roots was studied as follows. Cucumber seeds (Cucumis sativus L.) of Konkurent cultivar were treated with the mixture of ethyl alcohol and $50 \%$ hydrogen peroxide in 1:1 ratio for $30 \mathrm{~min}$, washed thrice with the sterile physiological solution and cultivated in potato agar in Petri dishes for $3-5$ days (depending on the batch). For preparation of the given medium $200 \mathrm{~g}$ of potato have been boiled in $1 \mathrm{~L}$ water, $\mathrm{pH} 7.0$ and $20 \mathrm{~g}$ agar was added. The roots of sterile sprouts obtained were cut into segments of $1-1.5 \mathrm{~cm}$ and introduced in portions of $100 \mathrm{mg}$ into the $10 \mathrm{~cm}$ long tubes with the diameter of $20 \mathrm{~mm}$. Washed with Na-K phosphate buffer ( $\mathrm{pH}$ 7.0) of the bacterial suspension $(3 \mathrm{~mL})$ containing at least $10^{8}$ cells $/ \mathrm{mL}$ was added to the tubes containing the cucumber roots. The tubes were placed in the shaker (type W-4, Premed, Poland, $130 \mathrm{rpm}$ ) and incubated at room temperature $\left(19-21^{\circ} \mathrm{C}\right)$ for $1 \mathrm{~h}$. The roots were washed thrice with the sterile physiological solution at the microshaker type ML-1 (Premed, Poland), homogenized in the mortar and made up to the volume of 10 $\mathrm{ml}$ using the physiological solution. The number of adhered living cells was determined by the number of colonies (colony-forming units, CFU) growing on the agarised potato medium in Petri dishes after the homogenate from ten-fold dilutions was plated and expressed as CFU per $1 \mathrm{~g}$ of wet weight of the roots. All the experiments were conducted at least thrice in three replicas.

The motility of bacteria was estimated in a "hanging drop" using microscopy (Yegorov 1959), the hydrophobicity of their surface was determined by the 
distribution of cells in the "suspension of bacteria-n-hexadecane" system (Rosenberg and Kjelleberg 1986).

\section{Determination of lectins in Bacillus}

The presence of lectins in Bacillus was determined by the results of hemagglutination reaction (HAR) in two-fold dilutions in series in sterile U-like 96-well polystyrene microplates at room temperature using trypsinized rabbi erythrocytes, fixed with glutaraldehyde (Lutsyk et al. 1980). The control was selected as $2 \%$ suspension of erythrocytes in the physiological solution.

The carbohydrate specificity of surface lectins of bacilli was studied after $50 \mathrm{~h}$ of their cultivation in the abovementioned medium according to the reaction of hemagglutination inhibition (Lutsyk et al. 1980). The following carbohydrates and glycoproteins were used for this purpose: D-galactose, $\alpha$-D-glucose, Dxylose, furanose (Institute of Chemistry, Czech Republic), N-acetyl-Dgalactosamine, D-galactosamine chloride, D-glucosamine chloride, D-mannose (Chemapol, Czech Republic), L-ramnose, L-ribose, D-fructose (Pharmacia, Switzerland), L-arabinose, glucoso-6-phosphoric acid, phosphogluconic acid, fructoso-1,6-biphosphate (Reanal, Hungary), 2-deoxy-D-glucose, lactose, maltose, $\alpha$-methyl-D-mannoside, $\beta$-D-thioglucose, methyl- $\alpha$-D-glucopiranoside (Serva, Germany), D-galacturonic acid, D-glucuronic acid, dulcite, inositol, Dmannitol, sorbitol (Institute of Bioorganic Chemistry, RAS, Russia).

The degree of HAR inhibition was expressed as a minimal dose of carbohydrate, required for complete inhibition of HAR, and defined as the last dilution, when the inhibition of the reaction of hemagglutination of erythrocytes is still observed To study the impact of carbohydrates on bacteria adhesion to the cucumber roots, the cells were precipitated by centrifugation (OPN-8, Bishkek, Kirgiziya ) a $5.000 \mathrm{~g}$ for $15 \mathrm{~min}$, washed with the physiological solution three times, then resuspended in the latter making the optic density of the suspension up to 0.4 units. Then it was titrated in the wells by the addition of $0.05 \mathrm{ml}$ of bacteria suspension to the dilutions $0.05 \mathrm{ml}$ of $0.3 \mathrm{M}$ solution of D-glucosamine chloride and inculbated under ambient conditions for $1 \mathrm{~h}$. The cells were precipitated in the above-mentioned conditions and washed with the physiological solution; the optic density of the prepared suspension was 0.4 units. Then $0.1 \mathrm{~g}$ of cucumber roots was added $2 \mathrm{~mL}$ of the obtained suspension of cells and left for $1 \mathrm{~h}$ at room temperature. The roots were washed thrice with the physiological solution to remove the non-adhered cells, triturated in the mortar with $10 \mathrm{ml}$ of the physiological solution and plated as dilution series on agarised potato medium The number of colonies was counted with their subsequent calculation per $1 \mathrm{~g}$ of wet roots. In the control variant of experiments the cells of bacilli were treated with the physiological solution. In one experimental variant the cells of bacteria were not washed off the carbohydrate after the interaction with the latter.

\section{Statistical analysis}

Microsoft excel (Microsoft Corporation, USA) was used to analyze data on the average of three replicates $( \pm \mathrm{SE})$ obtained from three independent experiments Differences were compared for statistical significance at the P-level less than $0.05(\mathrm{P}<0.05)$ (Lakin 1990).

\section{Results and Discussion}

The adhesion of bacteria is known to depend on many factors, including the stage of culture development (Kurdish et al. 1998). We have demonstrated that the cells of B. subtilis, cultivated for $24 \mathrm{~h}$, adhered to the surface of glass granules in the maximal amount in the exponential growth phase. In the latter case $(1.24 \pm 0.06) \cdot 10^{8}$ cells were sorbed to $1 \mathrm{~g}$ of glass. The bacteria, cultivated for 48 and $72 \mathrm{~h}$, adhered to glass in a lesser amount. Their number on the glass amounted to $(0.55 \pm 0.03) \cdot 10^{8}$ and $(0.49 \pm 0.03) \cdot 10^{8}$ cells/ $1 \mathrm{~g}$ of glass, respectively (Fig. 1).

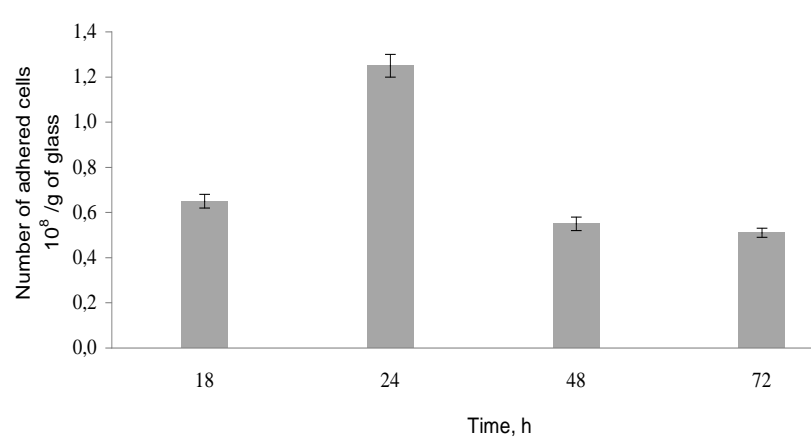

Figure 1 The adhesion of Bacillus subtilis IMV B-7023 to glass particles depending on the time of cultivation

The results required explanation of the differences in the adhesion to the glass surface of bacteria cultivated during different time periods. to the glass surface.
An important factor defining the efficiency of bacteria adhesion to solid materials, is known to be the hydrophobicity of interacting surfaces (Kurdish 2010; Kurdish et al. 1998; Fletcher 1979). We have studied the dependence of the surface hydrophobicity of B. subtilis IMV B-7023, on the phase of development. During the cultivation period of $18 \mathrm{~h}$ this index amounted only to 7 $\%$ (Fig. 2).

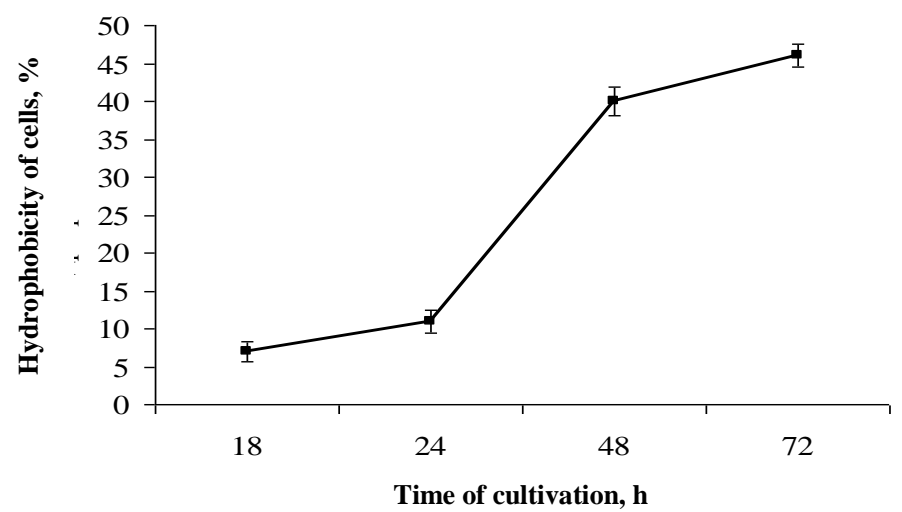

Figure 2 The dependence of hydrophobicity of Bacillus subtilis IMV B-7023 on the duration of cultivation

With the prolongation of the duration of bacilli cultivation to $24 \mathrm{~h}$ the hydrophobicity of cells increased up to $11 \%$, and after 48 and $72 \mathrm{~h}$ of cultivation - up to 40 and $46 \%$, respectively. Therefore, regardless of the significant role of hydrophobic interaction in bacteria adhesion (Fletcher

1979; Kurdish et al. 1998), this factor did not play the decisive role in the maximal adhesion of $B$. subtilis to glass particles after $24 \mathrm{~h}$ of the cultivation.

Our further experiments have shown that a considerable impact on the adhesion process is made by the motility of cells (Kurdish 2010). The microscopy of bacteria suspension samples, taken after $24 \mathrm{~h}$ of cultivation, testifies to the fact that all the cells of the population are mobile.

At the same time the majority of bacteria, cultivated for $72 \mathrm{~h}$, were immobile and had the form of spores. Therefore, an important factor, determining the adhesion of bacteria to the abiotic surface of glass, is the motility of B. subtilis cells. The surfaces of bacterial cells and glass are known for their negative charge. During their interaction there are repulsive forces, decreasing the adhesive properties of bacilli. However, the motility of cells allows bacteria to overcome the repulsive forces, occurring between these surfaces, and to adhere to negatively charged surfaces, including the glass particles (Fletcher 1979; Kurdish et al. 1998; Gordienko et al. 2009).

Quite a different principle was observed while studying the adhesion of B. subtilis IMV B-7023 to the cucumber roots. Here the extension of the cultivation period resulted in the improvement of adhesive properties of the studied cells until the stationary phase of growth $48 \mathrm{~h}$. Thus, after the 60 minute interaction of the cucumber roots and the bacteria, cultivated for $24-48 \mathrm{~h}$, the number of bacilli adhered to their surface was $0.88-2.3 \cdot 10^{6}$ cells $/ g$ (Fig. 3) When $B$. subtilis were cultivated longer $(72 \mathrm{~h})$, only $0.35 \cdot 10^{6} \mathrm{CFU} / \mathrm{g}$ adhered to the cucumber roots which came up to only $15.2 \%$ from the number of adhered cells selected from the stationary phase of growth $(48 \mathrm{~h})$.

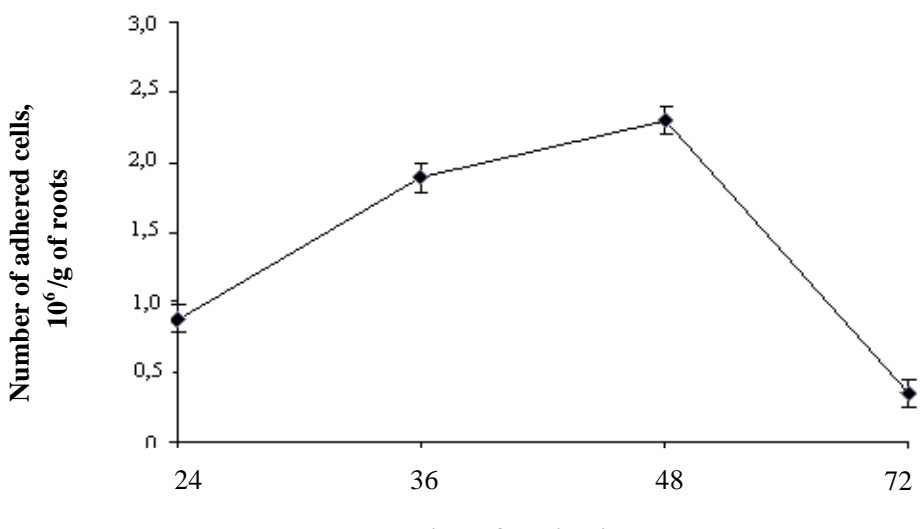

Time of cultivation, $h$

Figure 3 The adhesion of Bacillus subtilis IMV B-7023 to the cucumber roots depending on the duration of bacteria cultivation 
These differences in the adhesion of bacilli to the cucumber roots were possibly caused by the specific interaction between $B$. subtilis and the root surface of these plants. There were found the lectins localized on the surface of phosphatemobilizing bacteria B. subtilis IMV B-7023. The mentioned lectins are known for certain carbohydrate specificity.

The most vivid manifestation of the lectin activity regarding the trypsinized rabbit erythrocytes was observed for B. subtilis IMV B-7023 after $48 \mathrm{~h}$ of cultivation. The reaction of inhibiting the hemagglutination of rabbit erythrocytes with B. subtilis IMV B-7023 bacterial cells demonstrated that out of 30 carbohydrates tested in this study the carbohydrate specificities of surface lectins were observed only regarding D-glucosamine chloride $(0.05 \mathrm{M})$, D-galacturonic $(0.1 \mathrm{M})$ and $\mathrm{D}$-glucuronic acids $(0.00625 \mathrm{M})$

The highest affinity of surface lectins of B. subtilis IMV B-7023 was demonstrated to D-glucosamine chloride. The interaction between bacterial cells and the carbohydrate, towards which the specificity of the lectins of bacilli was revealed, diminished the adhesion of cells to the cucumber roots considerably. Not treated with the carbohydrate $9.3 \cdot 10^{6}$ bacterial cells sorbed per $1 \mathrm{~g}$ of roots was taken as $100 \%$ control. In the case D-glucosamine chloride treatment the adhesion of bacilli to the cucumber roots decreased by $26 \%$ being $6.9 \cdot 10^{6} \mathrm{CFU} / \mathrm{g}$ of roots (Fig. 4)

The obtained results testifed to the great importance of the surface lectins for the adhesion of Bacillus subtilis IMV B-7023 to the cucumber roots. It is noteworthy that the representatives of Bacillus genus along with the surface lectins are also capable of synthesizing extracellular lectins (Podgorskii et al. 2014).

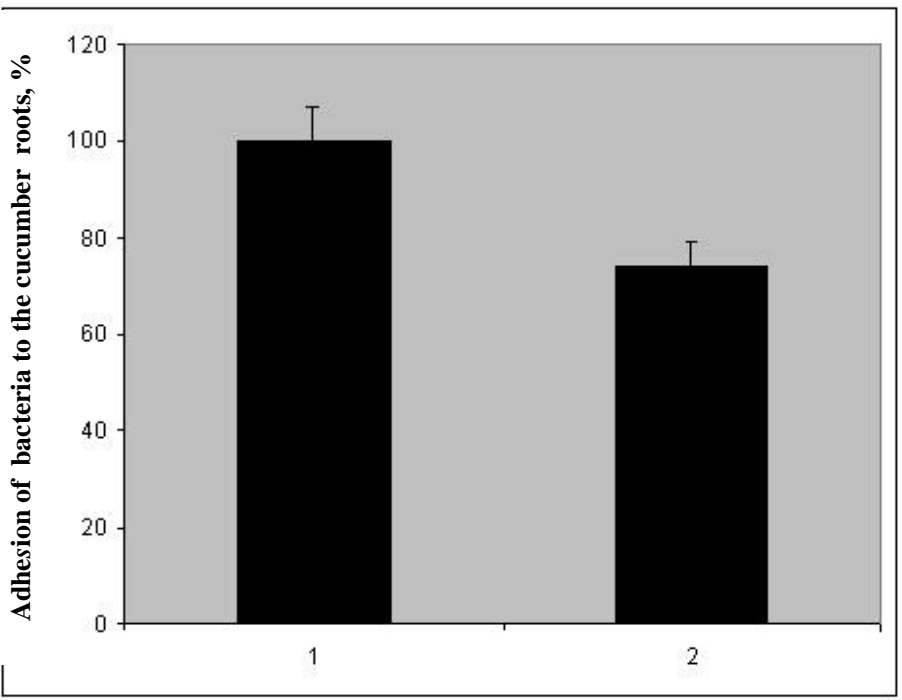

Figure 4 The impact of lectin-carbohydrate interaction on the adhesion of Bacillus subtilis IMV B-7023 to the cucumber roots, Konkurent cultivar. The adhesion of bacteria in the control (1) and after their treatment with Dglucosamine chloride (2).

It has recently been shown that many bacteria use carbohydrate-specific lectins which are expressed as part of capillary protein appendages expanding from their surface called fimbrie or pili for the adhesion to biotic surfaces (Mirja Hartmann and Thisbe Lindhourst 2011). A relevant role of the surface lectins was established for the adhesion of Azospirillum brasilense Sp1 to wheat roots and for the formation of defensive reactions of plants (Nikitina 2001). For instance, it was demonstrated that the treatment of wheat seeds with the solution containing $40 \mu \mathrm{g} \mathrm{ml}^{-1}$ of Azospirillum brasilense Sp1 lectin lead to the synthesis of nitrogen oxide in the roots of sprouts, which is one of the inducers of the processes of adaptation of these plants to stress factors (Alen'kina, Nikitina 2010).

Therefore, the surface lectins of $B$. subtilis IMV B-7023 plaied a significant role in the adhesion of bacteria to the biotic surfaces (cucumber roots). They played the role of adhesins in this process. At the same time when these bacteria interacted with abiotic surfaces, the leading role was played by the motility of cells helping to overcome the repulsive forces between negatively charged surfaces of bacteria and glass particles and ensure the adhesion of cells to a solid surface.

\section{REFERENCES}

COSTERTON, J.W., MARRIE, M.J., CHENG, K. J. 1985. Phenomena of bacterial adhesion. In Costerton J.W. (ed) Bacterial adhesion: Mechanism and physiological significance. Plenum press, London, New York, 3 - 43. http://dx.doi.org/10.100/978-1-4615-6514-71

FLETCHER, M. 1979 Adhesion of microorganisms to surfaces. Acad. Press London.

GORDIENKO, A.S., BEGA, Z.T., DYRENKO, D.I., KURDISH, I.K. 2009
Adhesion of Azotobacter vinelandii IMV B-7076 and Bacillus subtilis IMV B7023 to different surfaces. Mikrobiologichny Zhurnal, 71, 13-18.

NIKITINA, V.E. 2001. Azospirillum lectins - properties, biological activity and prospects of their application. Sc. D. (biology) thesis. Saratov. 310p.

KARPUNINA, L.V. 2005. Role of agglutinating proteins of rhizobia and nitrogen-fixing bacilli in the interaction with plants. In Karpunina L.V. (ed.) Molecular basics of interactions between microorganisms and plants. Nauka, Moscow, 98-117.

KURDISH, I.K. 2010. Introduction of microorganisms into agroecosystems. Naukova dumka, Kyiv. 253p.

KURDISH, I.K., GORDIENKO A.S., KYGEL N.F., KYSTEN A.G. 1998 Comparative analysis of adhesion of different kinds of methanotropic bacteria to solid materials. Appl. Biochem. and Microbiol, 34,245-250.

LAKIN, G.F. 1990. Biometry. Vysshaia shkola, Moscow.

LUTSYK, M.D., PANASYK, E.N., ANTANIUK, V.A. 1980. Methods of searching for lectins (phytohemagglutinins) and determination of their immunochemical specificity. Lviv.20 p.

PATENT №. 54923A. Bacterial strain Bacillus subtilis to obtain bacterial fertilizers for crop production / I.K. Kurdish, A.O. Roi, Ukraine. Appl. dated May 22, 2002. Published on March 17, 2003. Bul. №. 3 .

PODGORSKY, V.S., KOVALENKO, E.A., SYMONENKO, I.A. 1992. Lectins of bacteria. Naukova dumka, Kyiv.

ROSENBERG, M., KJELLEBERG, S. 1986. Hydrophobic Interactions: Role in bacterial adhesion. Microb. Ecol, 9:353-393. http://dx.doi.org/10.1007/978-1 4757-0611-68

SHARON, N., LIS, H. 2007. Lectins. Academic Publishers, London. http://dx.doi.org/10.1007/978-1-4020-6953-6

YEGOROV, N.S. 1959. Guide to practical classes in microbiology. $M G U$ Publishing House .Moscow.

ZVIAGINTSEV, D.G., GUZEV, V.S., GUZEVA, I.S. 1977. Adsorption of microorganisms relative to the stages of their development. Microbiologia, $46,295-299$

HARTMANN, M. and Lindhorst, T. 2011. The Bacterial Lectin FimH, a Target for Drug Discovery - Carbohydrate Inhibitors of Type I Fimbriae-Mediated Bacterial Adhesion.//European Journal of Organic Chemistry v.2011, 20-21. 3583-3609.

http://dx doi.org/10.1002/ejoc.201100407.

ALELEN'KINA, S.A., NIKITINA, V.E. 2010. Azospirillum lectin-induced changes in the content of nitric oxide in wheat seedling root// Journal of Stress Physiology \&Biochemistry 6, №4. 126-134. 